\title{
MYCOTOXIN RESEARCH IN BRAZIL: THE LAST DECADE IN REVIEW
}

\author{
Delia B. Rodríguez-Amaya ${ }^{1}$; Myrna Sabino ${ }^{2 *}$ \\ ${ }^{1}$ Departamento de Ciência de Alimentos, Faculdade de Engenharia de Alimentos, Universidade Estadual de Campinas, \\ Campinas, SP, Brasil. ${ }^{2}$ Seção de Química Biológica, Instituto Adolfo Lutz, São Paulo, SP, Brasil \\ Submitted: January 29, 2002. Approved: February 25, 2002
}

\begin{abstract}
REVIEW
ABSTRACT

The number of research papers (128 papers) on mycotoxins published by Brazilian researchers in 1991-2000 surpassed the total number (85 papers) published in the preceding three decades (1961-1990). Thirty percent of the papers surveyed mycotoxins in foods and feeds. AFs in peanut and peanut products continued to be alarming, and high incidence and levels of FBs in corn and corn products also appeared as a serious problem. Contamination with other toxins, such as ZEA, OTA and trichothecenes, was low. Occurrence of $\mathrm{AFM}_{1}$ in milk and dairy products and patulin in apple juice needs to be verified as the results are somewhat diverging. Work on analytical methods, mycological examination and toxic effects constituted 16,13 and 13\%, respectively, of the published papers in the decade assessed. Attempts to find means of preventing/controlling fungal growth and mycotoxin production notably increased, making up $27 \%$ of the papers, including investigations on influencing factors (e.g. genotype resistance, water content $/ a_{w}$, relative humidity, temperature, presence of metals, type of soil, mite infestation) and antagonistic potential of other microorganisms against mycotoxin-producing fungi. Effects of plant extract, flavonoids, fungicides and other chemicals, storage bag material, adsorbents, cooking and processing of food were also studied. Thus, notwithstanding constraints on resources, Brazilian research responds to the needs of the country, reflects international concerns and recent developments in the area.
\end{abstract}

Key words: mycotoxins, occurrence, influencing factors, research, Brazil

\section{INTRODUCTION}

As a continuation of a review article published in 1993 (109), which integrated published research on mycotoxins in Brazil from 1961 to 1990 , the present review examines papers published by Brazilian researchers in national and international journals in one decade, 1991-2000. Investigations in this area intensified in this decade, the number of papers (128 research papers) surpassing the total number published in the preceding three decades $(85$ research papers). The studies also showed an evident widening of scope and depth. In 1961-1990, most of the investigations involved only aflatoxins and were conducted in the state of São Paulo. In the last decade, other mycotoxins were also studied and researchers from other states gave significant contribution.
There was also a shift in focus. In 1961-1990, the distribution of the papers according to topic was: occurrence of mycotoxins, 38 papers (45\%); analytical methods, 11 papers $(13 \%)$; microbiological studies, 12 papers (14\%); prevention, control and effects of food processing, 12 papers (14\%); mycotoxicoses, toxic effects, 12 papers (14\%). In the decade 1991-2000, the papers were distributed as follows: occurrence of mycotoxins, 39 papers (30\%); analytical and mycological methods, 20 papers (16\%); mycological surveys and mycotoxin-producing potential, 17 papers (13\%); prevention, control and effects of food processing, 35 papers $(27 \%)$; toxic effects and mode of action, 17 papers $(13 \%)$. Although the incidence of mycotoxins continued to receive the most attention, its percentage in relation to the total number of papers declined. There was a considerable increase in

\footnotetext{
* Corresponding author. Mailing address: Av. Dr. Arnaldo, 355. Instituto Adolfo Lutz, Seção de Química Biológica, 01246-902, São Paulo, SP, Brasil. Phone: (+5511) 3068-2921, FAX (+5511) 3085-3505. E-mail: mysabino@ial.sp.gov.br
} 
research on prevention, control and processing effects. These changes indicate that Brazilian investigators are shifting from verifying the existence and magnitude of mycotoxin problems to finding ways and means of diminishing the problem.

\section{OCCURRENCE OF MYCOTOXINS}

Considering year-to-year variations and differing climate, agricultural practices, post-harvest handling, processing and storage conditions in different parts of a country, especially a huge country like Brazil, the information given in Table 1 should not be taken as absolute but as indicative of the existing situation. Nevertheless, some trends can be discerned.

Aflatoxins (AFs) in peanuts and peanut products continued to be an alarming problem, although the extent and levels were generally lower than reported previously (109). AF occurrence in corn, the commodity internationally considered to be most susceptible to AF contamination, was much lower, occurring only occasionally. As in other parts of the world, including other Latin American countries, there was widespread, high contamination of corn and corn-based products with fumonisins (FBs). Incidence of other mycotoxins, such as zearalenone (ZEA), ochratoxin A (OTA) and trichothecenes, was low. Occurrence of aflatoxin $\mathrm{M}_{1}\left(\mathrm{AFM}_{1}\right)$ and patulin (PAT) needs verification because the results diverge somewhat.

Concern about ochratoxin contamination of coffee was recently raised, especially in Europe. Three surveys in Brazil $(50,97,124)$ (Table 1) showed that ochratoxin A, although detected, was present at very low levels in Brazilian coffee. Thus, contamination with this toxin does not appear to be a public health problem.

Aside from the surveys cited in Table 1, the incidence of macrocyclic trichothecenes in Brazilian Baccharis species (shrub) was also investigated, only $B$. cardifolia and $B$. megapotamica being found to contain these toxins (49).

\section{ANALYTICAL AND MYCOLOGICAL METHODS}

In the surveys presented in Table 1, aflatoxins B (AFBs) and G(AFGs) were generally determined by thin layer chromatography (TLC); FBs and PAT by high performance liquid chromatography (HPLC); $\mathrm{AFM}_{1}$ by TLC, HPLC and enzyme-linked immunosorbent assay (ELISA); trichothecenes by gas chromatography (GC) and TLC; ZEA and OTA by TLC, in various papers together with AFs and esterigmatocystin by a multi-toxin TLC method (125). OTA specifically in coffee was determined by HPLC.

Work on methodology continued during this period. TLC methods for the determination of trichotecenes and ZEA in grains (58) and of $\mathrm{AFB}_{1}, \mathrm{AFM}_{1}, \mathrm{ZEA}$ and OTA in animal tissues (126), an HPLC method for the simultaneous determination of tenuazonic acid (TEA) and cyclopiazonic acid (CPA) (71), a method for determining $\mathrm{FB}_{1}$ in corn, using immunoaffinity column clean-up and TLC/densitometry (101), and an HPLC method involving fluorimetric quantification of OPA-derivatives of $\mathrm{FB}_{1}$ and $\mathrm{FB}_{2}$ in corn and Fusarium moniliforme culture extracts (23) were developed. A GC method for quantification and confirmation of trichothecenes in wheat (40), TLC systems for the confirmation of trichothecenes (59) and a commercial ELISA kit for $\mathrm{AFM}_{1}$ in milk (74) were assessed. Comparisons were carried out with ELISA and TLC methods for $\mathrm{AFB}_{1}$ in samples of corn, feed and peanut (106) and for AFs, OTA and ZEA in corn and corn meal (63); two TLC methods for OTA in green coffee (66); and TLC and HPLC methods for $\mathrm{AFM}_{1}$ in milk (116) and for $\mathrm{FB}_{\mathrm{S}}$ in corn (80). Screening methods for AFs in corn and peanut were also evaluated $(44,83,119)$. A sampling scheme was proposed for AF analysis in grains (29) and anomalous recoveries of AF from peanut and Brazil nuts measured by ELISA was reported (26).

A method for inoculating peanuts with A. flavus was standardized (88) and a simple and rapid method for screening high numbers of soil microorganisms capable of producing antifungal substances against $F$. moniliforme was developed (67).

\section{MYCOLOGICAL SURVEYS AND MYCOTOXIN- PRODUCING POTENTIAL}

Compared to previous decades, mycological examination increased in number but decreased slightly in percentage of the total number of papers during the period assessed. Some of these studies accompanied mycotoxin surveys and/or evaluated correlation with abiotic conditions. Corn was the most investigated commodity, and mycotoxigenic molds were found at high frequency in this food. Thus, the potential for mycotoxin production exists although, except for FBs, the occurrence of other mycotoxins in corn has been low in Brazil.

Aflatoxins were not detected in 10 varieties of recently harvested corn from Minas Gerais (1992-93 season) but there was high fungal contamination, with massive infection of Fusarium (100\%), followed by Penicillium (60\%) and Aspergillus (35\%) (72). The highest moisture content was 14\%. Among 20 Aspergillus isolates, $35 \%$ belonged to the species A. fumigatus, $30 \%$ to A. flavus, $30 \%$ to A. niger and $5 \%$ to A. ochraceus. Three of 6 strains of A. flavus were able to produce $\mathrm{AFB}_{1}$.

In 130 samples of postharvest and stored corn from São Paulo (1991 harvest), Fusarium spp. was also the dominant fungi (84\%), followed by Penicillium spp (55\%) and Aspergillus spp. (41\%) (85). However, only one sample had $\mathrm{AFB}_{1}$; OTA, ZEA and DON were not detected. The Fusarium genus (but not Penicillium and Aspergillus) had significant positive correlation with moisture content of the grains and significant negative correlation with minimum and medium temperatures, rainfall and relative humidity. Similarly, in 195 samples of three hybrids of corn, analyzed monthly during one year, Fusarium spp. predominated, followed by Penicillium spp. and Aspergillus spp. (82) Fusarium moniliforme was the most prevalent Fusarium species. 
Table 1. Incidence and levels of mycotoxins in foods and feeds.

\begin{tabular}{|c|c|c|c|c|c|c|c|}
\hline \multirow{2}{*}{$\begin{array}{l}\text { Origin of sample/ } \\
\text { Reference }\end{array}$} & \multirow{2}{*}{$\begin{array}{l}\text { Crop } \\
\text { year }\end{array}$} & \multirow{2}{*}{ Mycotoxin } & \multirow{2}{*}{ Commodity } & \multirow{2}{*}{$\begin{array}{l}\text { Positive/ Total } \\
\text { no. of samples }\end{array}$} & \multicolumn{2}{|c|}{ Positive samples $(\mu \mathrm{g} / \mathrm{kg})$} & \multirow{2}{*}{$\begin{array}{c}\text { Analytical } \\
\text { Tech }\end{array}$} \\
\hline & & & & & Range & Mean & \\
\hline Federal District (113) & $85-95$ & $\mathrm{AFB}_{1}+\mathrm{AFG}_{1}$ & Peanut, prods. & $89 / 450$ & $<10-600$ & NA & TLC \\
\hline São Paulo (36) & 1988 & $\mathrm{AFB}_{1}+\mathrm{AFG}_{1}$ & "Paçoca" & $194 / 316$ & 4-195 & NA & TLC \\
\hline São Paulo (31) & 1988 & $\mathrm{AFB}_{1}+\mathrm{AFG}_{1}$ & Peanut & $270 / 517$ & $5-1150$ & 134 & TLC \\
\hline \multirow{2}{*}{ São Paulo (104) } & 1989 & $\mathrm{AFB}_{1}+\mathrm{AFG}_{1}$ & Peanut & $37 / 108$ & $9-12999$ & 415 & TLC \\
\hline & 1994 & $\mathrm{AFB}_{1}+\mathrm{AFG}_{1}$ & Peanut, prods. & $142 / 321$ & $>5-2440$ & 305 & TLC \\
\hline São Paulo (105) & $95-97$ & $\mathrm{AFB}_{1}+\mathrm{AFG}_{1}$ & Peanut, prods. & $62 / 137$ & $>5-536$ & NA & TLC \\
\hline \multirow[t]{2}{*}{ São Paulo (8) } & 1994 & $\mathrm{AFB}_{1}$ & Peanut, prods. & $32 / 66$ & $28-997$ & 133 & TLC \\
\hline & 1994 & $\mathrm{AFG}_{1}$ & Peanut, prods. & & 14-149 & & \\
\hline São Paulo (37) & $95-96$ & AFs & Peanut, prods. & $41 / 80$ & 43-1099 & 399 & TLC \\
\hline Goiás (79) & NA & $\mathrm{AFB}_{1}+\mathrm{AFG}_{1}$ & Peanut & $40 / 104$ & $37-522$ & 187 & TLC \\
\hline \multirow[t]{4}{*}{ Pernambuco (6) } & 1993 & $\mathrm{AFB}_{1}$ & Peanut & $26 / 86$ & $10-2000$ & 420 & TLC \\
\hline & 1993 & $\mathrm{AFB}_{2}$ & Peanut & $20 / 86$ & $10-400$ & 134 & TLC \\
\hline & 1993 & $\mathrm{AFG}_{1}$ & Peanut & $6 / 86$ & $20-800$ & 207 & TLC \\
\hline & 1993 & $\mathrm{AFG}_{2}$ & Peanut & $6 / 86$ & $20-400$ & 95 & TLC \\
\hline \multirow[t]{4}{*}{ Paraná (61) } & $93-94$ & $\mathrm{AFB}_{1}$ & Peanut & $32 / 72$ & $1-679$ & 94 & TLC \\
\hline & $93-94$ & $\mathrm{AFB}_{2}$ & Peanut & $30 / 72$ & $1-192$ & 51 & TLC \\
\hline & $93-94$ & $\mathrm{AFG}_{1}$ & Peanut & $23 / 72$ & $1-680$ & 110 & TLC \\
\hline & $93-94$ & $\mathrm{AFG}_{2}$ & Peanut & $22 / 72$ & $1-320$ & 51 & TLC \\
\hline Santa Catarina (111) & $98-99$ & $\mathrm{AFB}_{1}+\mathrm{AFG}_{1}$ & Peanut, prods. & $16 / 131$ & $127(\max )$ & NA & TLC \\
\hline Rio Grande do Sul, & 1988 & $\mathrm{AFB}_{1}+\mathrm{AFG}_{1}$ & Corn & $11 / 36$ & $10-906$ & 131 & TLC \\
\hline Mato Grosso (47) & 1988 & ZEA, OTA & Corn & $0 / 36$ & - & - & TLC \\
\hline Minas Gerais (72) & $92-93$ & AFs & Corn & $0 / 40$ & - & - & TLC \\
\hline \multirow[t]{3}{*}{ São Paulo (85) } & 1991 & AFs & Corn & $1 / 130$ & 500 & - & TLC \\
\hline & 1991 & ZEA,OTA & Corn & $0 / 130$ & - & - & TLC \\
\hline & 1991 & DON & Corn & $0 / 130$ & - & - & TLC \\
\hline \multirow[t]{2}{*}{ Minas Gerais (95) } & 1991 & AFL, ZEA & Corn & $0 / 40$ & - & - & TLC \\
\hline & 1991 & OTA, DON & Corn & $0 / 40$ & - & - & TLC \\
\hline \multirow{2}{*}{$\begin{array}{l}\text { São Paulo, Paraná } \\
\text { Mato Grosso (Sul) }\end{array}$} & $93-94$ & $\mathrm{AFB}_{1}$ & Corn & $97 / 292$ & $2-89$ & NA & TLC \\
\hline & $93-94$ & $\mathrm{AFB}_{2}$ & Corn & $33 / 292$ & $1-17$ & NA & TLC \\
\hline Mato Grosso & $93-94$ & AFG & Corn & $13 / 292$ & $2-85$ & NA & TLC \\
\hline \multirow[t]{2}{*}{ Goiás (43) } & $93-94$ & AFG & Corn & $7 / 292$ & $1-6$ & NA & TLC \\
\hline & 93-94 & ZEA, OTA & Corn & $0 / 292$ & - & - & TLC \\
\hline \multirow{2}{*}{$\begin{array}{c}\text { Brazil, Argentina } \\
\text { Paraguay (98) }\end{array}$} & $94-95$ & DON & Corn & $7 / 115$ & $102-542$ & NA & TLC \\
\hline & $94-95$ & $\mathrm{~T}-2$ & Corn & $1 / 115$ & 104 & - & ELISA \\
\hline \multirow{2}{*}{$\begin{array}{l}\text { Rio Grande do Sul } \\
\text { (39) }\end{array}$} & $96-97$ & $\mathrm{AFB}_{1}$ & Corn prods. & $3 / 39$ & $30-163$ & 75 & TLC \\
\hline & $96-97$ & ZEA, OTA & Corn prods. & $0 / 39$ & - & - & TLC \\
\hline Mato Grosso (22) & 1999 & AFs & Corn & $64 / 140$ & $2-431$ & NA & ELISA \\
\hline \multirow{2}{*}{$\begin{array}{l}\text { Paraná, Mato Grosso } \\
\text { do Sul, Goiás (48) }\end{array}$} & $90-91$ & $\mathrm{FB}_{1}$ & Corn & $47 / 48$ & $600-18500$ & 5490 & HPLC \\
\hline & $90-91$ & $\mathrm{FB}_{2}$ & Corn & $46 / 48$ & $1200-19130$ & 4820 & HPLC \\
\hline \multirow[t]{2}{*}{ Paraná(81) } & $95-96$ & $\mathrm{FB}_{1}$ & Corn & $149 / 150$ & $70-13460$ & NA & HPLC \\
\hline & $95-96$ & $\mathrm{FB}_{2}$ & Corn & $138 / 150$ & $80-6920$ & NA & HPLC \\
\hline \multirow[t]{2}{*}{ São Paulo (82) } & NA & $\mathrm{FB}_{1}$ & Corn & $176 / 195$ & $870-49310$ & 9730 & HPLC \\
\hline & NA & $\mathrm{FB}_{2}$ & Corn & $190 / 195$ & $1960-29160$ & 7600 & HPLC \\
\hline São Paulo (55) & 1999 & $\mathrm{FB}_{1}$ & Corn prods. & $40 / 81$ & $30-4930$ & 1180 & HPLC \\
\hline & 1999 & $\mathrm{FB}_{2}$ & Corn prods. & $44 / 81$ & $20-1380$ & 290 & HPLC \\
\hline São Paulo (21) & $92-93$ & $\mathrm{AFM}_{1}$ & Raw milk & $0 / 144$ & - & - & TLC \\
\hline São Paulo (118) & 1989 & $\mathrm{AFM}_{1}$ & $\begin{array}{l}\text { Pasteurized, } \\
\text { powdered milk }\end{array}$ & $0 / 86$ & - & - & TLC \\
\hline & 1990 & $\mathrm{AFM}_{1}$ & Cheese, yoghurt & $0 / 66$ & - & - & HPLC \\
\hline & 1992 & $\mathrm{AFM}_{1}$ & Pasteurized milk & $4 / 52$ & $0.07-.37^{1}$ & $156^{1}$ & HPLC \\
\hline
\end{tabular}


Table 1 (continuação). Incidence and levels of mycotoxins in foods and feeds.

\begin{tabular}{|c|c|c|c|c|c|c|c|}
\hline \multirow{2}{*}{$\begin{array}{l}\text { Origin of sample/ } \\
\text { Reference }\end{array}$} & \multirow{2}{*}{$\begin{array}{l}\text { Crop } \\
\text { year }\end{array}$} & \multirow{2}{*}{ Mycotoxin } & \multirow{2}{*}{ Commodity } & \multirow{2}{*}{$\begin{array}{l}\text { Positive/ Total } \\
\text { no. of samples }\end{array}$} & \multicolumn{2}{|c|}{ Positive samples $(\mu \mathrm{g} / \mathrm{kg})$} & \multirow{2}{*}{$\begin{array}{c}\text { Analytical } \\
\text { Tech } \\
\end{array}$} \\
\hline & & & & & Range & Mean & \\
\hline São Paulo (75) & $92-93$ & $\mathrm{AFM}_{1}$ & $\begin{array}{l}\text { Reconstituted } \\
\text { milk power }\end{array}$ & $33 / 300$ & $.10-1.00^{1}$ & $270^{1}$ & ELISA \\
\hline Minas Gerais (100) & $96-98$ & $\mathrm{AFM}_{1}$ & cheese & $56 / 75$ & $0.02-6.92$ & 0.45 & HPLC \\
\hline \multirow[t]{2}{*}{ Rio de Janeiro (32) } & NA & $\mathrm{AFB}_{1}$ & egg & $2 / 120$ & 2,5 & 3 & TLC \\
\hline & NA & $\mathrm{AFM}_{1}$ & egg & $0 / 120$ & - & - & TLC \\
\hline Santa Catarina, Rio & NA & $\mathrm{AFB}_{1}$ & Swine liver and & $1 / 43$ & 27 & - & TLC \\
\hline \multirow[t]{3}{*}{ Grande do Sul (108) } & & $\mathrm{AFM}_{1}$ & kidney & $0 / 43$ & - & - & TLC \\
\hline & & $\mathrm{AFB}_{1}$ & Poultry liver and & $0 / 40$ & - & - & TLC \\
\hline & & $\mathrm{AFM}_{1}$ & kidney & $1 / 40$ & trace & - & TLC \\
\hline \multirow[t]{4}{*}{ Rio de Janeiro (25) } & NA & $\mathrm{AFB}_{1}$ & Chicken liver & $3 / 6$ & $1.2-3.2$ & 2.1 & TLC,HPLC \\
\hline & $88-90$ & AFs, ZEA & Wheat & $0 / 18$ & - & & TLC \\
\hline & $88-90$ & OTA & Wheat & $1 / 18$ & 40 & - & TLC \\
\hline & $88-90$ & DON & Wheat & $1 / 18$ & 400 & - & $\mathrm{GC}$ \\
\hline \multirow{5}{*}{$\begin{array}{c}\text { Brasil, Argentina, } \\
\text { Uruguay (41) }\end{array}$} & $88-90$ & DAS & Wheat & $1 / 18$ & 300 & - & $\mathrm{GC}$ \\
\hline & $88-90$ & $\mathrm{~T}-2$ & Wheat & $2 / 18$ & 350,360 & 355 & $\mathrm{GC}$ \\
\hline & $88-90$ & HT-2, NIV & Wheat & $0 / 18$ & - & - & GC \\
\hline & $88-90$ & $\mathrm{~T}-2$ tetraol & Wheat & $1 / 18$ & 1680 & - & GC \\
\hline & $88-90$ & $\mathrm{~T}-2$ triol & Wheat & $0 / 18$ & - & - & $\mathrm{GC}$ \\
\hline \multirow[t]{6}{*}{ São Paulo (42) } & 1990 & AFs, OTA & Wheat & $0 / 20$ & - & - & TLC \\
\hline & 1990 & ZEA & Wheat & $3 / 20$ & $130-400$ & 250 & TLC \\
\hline & 1990 & DON & Wheat & $4 / 20$ & $470-590$ & 550 & $\mathrm{GC}$ \\
\hline & 1990 & NIV & Wheat & $3 / 20$ & $160-400$ & 250 & GC \\
\hline & 1990 & $\mathrm{~T}-2$ & Wheat & $2 / 20$ & 400,800 & 600 & $\mathrm{GC}$ \\
\hline & 1990 & DAS & Wheat & $1 / 20$ & 600 & - & GC \\
\hline \multirow[t]{6}{*}{ São Paulo (122) } & 1991 & AFs, ZEA, OTA, & Wheat, prods. & $0 / 38$ & - & - & TLC \\
\hline & 1991 & DON & Wheat, prods. & $0 / 38$ & - & - & $\mathrm{GC}$ \\
\hline & 1991 & NIV, DAS, T-2, & Wheat, prods. & $0 / 38$ & - & - & $\mathrm{GC}$ \\
\hline & 1991 & HT-2, & Wheat, prods. & $0 / 38$ & - & - & GC \\
\hline & 1991 & T-2 triol, & Wheat, prods. & $0 / 38$ & - & - & $\mathrm{GC}$ \\
\hline & 1991 & $\mathrm{~T}-2$ tetraol & Wheat, prods. & $0 / 38$ & - & - & $\mathrm{GC}$ \\
\hline \multirow[t]{3}{*}{ Rio Grande do Sul (39) } & $96-97$ & $\mathrm{AFB}_{1}$ & Wheat prods. & $0 / 79$ & - & - & $\mathrm{GC}$ \\
\hline & $96-97$ & ZEA & Wheat prods. & $2 / 79$ & 97,105 & 101 & TLC \\
\hline & $96-97$ & OTA & Wheat prods. & $2 / 79$ & 18,26 & 22 & TLC \\
\hline \multirow[t]{3}{*}{ Rio Grande do Sul (127) } & $95-96$ & AFs & Flour & $0 / 54$ & - & - & TLC \\
\hline & $95-96$ & ZEA & Flour & $1 / 54$ & 53 & - & TLC \\
\hline & $95-96$ & OTA & Flour & $3 / 54$ & $2-23$ & 12 & TLC \\
\hline \multirow[t]{3}{*}{ Rio Grande do Sul (39) } & $96-97$ & $\mathrm{AFB}_{1}$ & Rice prods. & $1 / 47$ & 48 & - & TLC \\
\hline & $96-97$ & ZEA & Rice prods. & $0 / 47$ & - & - & TLC \\
\hline & $96-97$ & OTA & Rice prods. & $2 / 47$ & 19,35 & 27 & TLC \\
\hline São Paulo (123) & 1991 & $\begin{array}{l}\text { AFs,ZEA, } \\
\text { OTA }\end{array}$ & $\begin{array}{l}\text { Health foods, } \\
\text { Break. cereals }\end{array}$ & $0 / 103$ & - & - & $\begin{array}{l}\text { TLC } \\
\text { TLC }\end{array}$ \\
\hline Federal District (113) & $85-95$ & $\mathrm{AFB}_{1}+\mathrm{AFG}_{1}$ & Nuts & $1 / 117$ & 1200 & - & TLC \\
\hline \multirow[t]{5}{*}{ São Paulo (38) } & 1991 & AFL,ZEA, & Tree nuts & $0 / 56$ & - & - & TLC \\
\hline & 1991 & OTA & Tree nuts & $0 / 56$ & - & - & TLC \\
\hline & 1995 & $\mathrm{AFB}_{1}$ & Tree nuts & $2 / 54$ & $10-26$ & 18 & TLC \\
\hline & 1995 & $\mathrm{AFG}_{1}$ & Tree nuts & $1 / 54$ & 15 & - & TLC \\
\hline & 1995 & ZEA, OTA & Tree nuts & $0 / 54$ & - & - & TLC \\
\hline São Paulo & NA & OTA & C. arabica & $3 / 24$ & $1.7-13$ & 6.9 & HPLC \\
\hline Minas Gerais & NA & OTA & C. arabica & $8 / 37$ & $2.7-10$ & 5.9 & HPLC \\
\hline Paraná & NA & OTA & C. arabica & $0 / 7$ & - & - & HPLC \\
\hline
\end{tabular}


Table 1 (continuação). Incidence and levels of mycotoxins in foods and feeds.

\begin{tabular}{|c|c|c|c|c|c|c|c|}
\hline \multirow{2}{*}{$\begin{array}{l}\text { Origin of sample/ } \\
\text { Reference }\end{array}$} & \multirow{2}{*}{$\begin{array}{l}\text { Crop } \\
\text { year }\end{array}$} & \multirow{2}{*}{ Mycotoxin } & \multirow{2}{*}{ Commodity } & \multirow{2}{*}{$\begin{array}{l}\text { Positive/ Total } \\
\text { no. of samples }\end{array}$} & \multicolumn{2}{|c|}{ Positive samples $(\mu \mathrm{g} / \mathrm{kg})$} & \multirow{2}{*}{$\begin{array}{c}\text { Analytical } \\
\text { Tech }\end{array}$} \\
\hline & & & & & Range & Mean & \\
\hline Espirito Santo & NA & OTA & C. canephora & $0 / 4$ & - & - & HPLC \\
\hline Rondônia (124) & NA & OTA & C. canephora & $2 / 5$ & $5.5,114$ & 60 & HPLC \\
\hline Minas Gerais (97) & $98-99$ & OTA & $\begin{array}{c}\text { Coffee,roasted, } \\
\text { ground }\end{array}$ & $33 / 47$ & $0.99-5.87$ & 1.75 & HPLC \\
\hline \multirow{3}{*}{ São Paulo (50) } & \multirow{3}{*}{ NA } & OTA & Soluble coffee & $31 / 37$ & $0.25-2.00$ & 0.72 & HPLC \\
\hline & & \multirow[t]{2}{*}{ OTA } & $\begin{array}{c}\text { Coffee,roasted, } \\
\text { ground }\end{array}$ & $23 / 34$ & $0.3-6.5$ & & HPLC \\
\hline & & & Instant coffee & $14 / 14$ & $0.5-5.1$ & 2.2 & HPLC \\
\hline Paraná (54) & $92-93$ & PAT & Apple juice & $15 / 76$ & $6-77$ & 15 & HPLC \\
\hline \multirow[t]{2}{*}{ São Paulo (117) } & $92-93$ & PAT & Fruit, juice & $1 / 149$ & 17 & - & HPLC \\
\hline & 95 & PAT & Fruit, juice & $0 / 36$ & - & - & HPLC \\
\hline Federal District (113) & $85-95$ & $\mathrm{AFB}_{1}+\mathrm{AFG}_{1}$ & Various foods & $0 / 114$ & - & - & \\
\hline São Paulo (21) & $92-93$ & $\mathrm{AFB}_{1}$ & Feed & $14 / 96$ & $11-287$ & NA & TLC \\
\hline \multirow{2}{*}{$\begin{array}{l}\text { Rio Grande do Sul } \\
\text { (73) }\end{array}$} & $93-94$ & $\mathrm{AFB}_{1}$ & Corn for feed & $1 / 115$ & 10 & - & TLC \\
\hline & $93-94$ & ZEA & Corn for feed & $15 / 115$ & $413-4130$ & 1430 & TLC \\
\hline Amazonas (78) & 1995 & AFL & Feed & $0 / 60$ & - & - & TLC \\
\hline São Paulo, Paraná (45) & 1986 & $\mathrm{AFB}_{1}$ & Cottonseed meal & $114 / 169$ & $<10-40$ & NA & TLC \\
\hline
\end{tabular}

${ }^{1} \mathrm{mg} / \mathrm{l} ; \mathrm{NA}$ - data not available.

In 66 samples of three hybrids of freshly harvested corn from three regions of the state of São Paulo (1995 crop), the fungal population was also mainly composed of Fusarium spp., Penicillium spp., Aspergillus spp. and two other filamentous fungal genera, which were isolated from corn with $\mathrm{a}_{\mathrm{w}}$ of 0.30 to 0.99 and moisture content of 5 to $20 \%$ (1). The most frequent species of the genera Fusarium and Aspergillus were F. moniliforme and A. flavus. All of forty isolated strains of $F$. moniliforme produced $\mathrm{FB}_{1}$ and/or $\mathrm{FB}_{2}$. Of 10 A. flavus isolates, six strains produced $\mathrm{AFB}_{1}$ and/or $\mathrm{AFB}_{2}$. In 17 samples of freshly harvested corn from 16 different sites in the state of São Paulo in 1992, Fusarium and Penicillium incidence was also high; the genus Aspergillus was isolated but at a lower frequency (15). Four of $17 \mathrm{~A}$. flavus isolates were found to be $\mathrm{AFB}_{1}$ or $\mathrm{AFG}_{1}$ and $\mathrm{AFB}_{2}$ producers.

Of 39 corn samples from Parana and nine samples from Mato Grosso do Sul and Goias (1990-91 harvest), F. moniliforme and Aspergillus spp. section Flavi were detected in 41 and 33 samples, respectively (48). In a recent survey involving 150 samples of freshly harvested corn from the Central-Southern, Central-Western and Northern regions of the state of Parana, the samples were frequently contaminated with Fusarium spp. (99-100\%) and Penicillium spp. (93-100\%), Aspergillus spp. showing lower frequency (not detected to 28\%) (81). The highest contamination of potentially mycotoxigenic fungi occurred in corn from the Central-Western region. However, although FBs were found in all samples from the Central-Western and Northern regions, FB levels were higher in the North, the difference in FB contamination being attributed to the difference in rainfall levels.
In 90 samples of corn from various regions of Brazil (crop year not specified), Aspergillus, Penicillium, Fusarium, Rhizopus, Acremonium, Cladosporium, Neurospora and Pacilllomyces were the genera isolated (7). A. flavus was the most frequently isolated among the Aspergillus species from samples with moisture content between 14 and $18 \% ; 39 \%$ of the isolates were toxigenic and produced only $\mathrm{B}$ aflatoxins. A. parasiticus was the third most frequent species; all cultures were toxigenic and produced $\mathrm{AFB}_{1}, \mathrm{AFB}_{2}, \mathrm{AFG}_{1}$ and $\mathrm{AFG}_{2}$.

Five recently harvested corn hybrids produced in Rio Grande do Sul were examined in relation to macroscopic appearance, fungal contamination, AF production by Aspergillus parasiticus, NRRL 2999 and consumption of dry matter in fungal culture (24). The hybrids had macroscopic damage and showed fungal contamination by Penicillium spp. (14\%), Aspergillus spp. (24\%) and Fusarium spp. (57\%). AF production by the hybrids cultured for 5 and 10 days showed difference only in relation to $\mathrm{AFG}_{2}$ in cultures of 5 days.

F. graminearum was found in both local (12 samples) and imported (6 samples) wheat stored in elevators in Rio Grande do Sul, southern Brazil, in 1990 but not in the 1988-89 season (41). It was the main $F$. species in Argentinean and Uruguayan wheat, while $F$. dimerum predominated in Brazilian wheat. Twenty samples of two wheat cultivars from São Paulo (1990 harvest) had Alternaria, Drechslera, Epicoccum and Cladosporum as prevailing genera (42). Among the $F$. spp., F. semitectum was present in 19 samples and $F$. moniliforme in 18 samples; but F. graminearum was not found. 
The mycoflora of 140 samples of freshly harvested and stored sorghum was monitored for one year (112). There was a predominance of the genera Phoma (57\%), Aspergillus (43\%), Fusarium (25\%) and Rhizopus (21\%), along with the presence of nine other filamentous fungi. The species most frequently found were Aspergillus flavus and Fusarium moniliforme.

In 90 samples of milled rice negative to AFs from different regions in Brazil in 1987-88, Aspergillus, Penicillium, Cladosporium, Rhizopus and Rhodotorula were isolated (4). A. parasiticus was the most frequent of the Aspergillus genus, isolated from samples with moisture content of 14-17\%. All cultures were toxigenic, producing $\mathrm{AFB}_{1}, \mathrm{AFB}_{2}, \mathrm{AFG}_{1}$ and $\mathrm{AFG}_{2}$. A. flavus was the second most frequent, $22 \%$ of which was toxigenic, with the production of $\mathrm{AFB}_{1}$ or $\mathrm{AFB}_{1}$ and $\mathrm{AFG}_{1}$.

After milling of 30 samples of rough rice stored for 6, 12 or 24 months, samples of polished rice, rice bran and rice hull (30 samples each) were evaluated and the following fungi, in decreasing order of frequency, were found: Aspergillus spp., Nigrospora spp., Penicillium spp., Fusarium spp., Mucor spp., Cladosporium spp., Trichosporon spp. and non-sporulated fungi (52). Fungal contamination was lowest in polished rice, increasing progressively in samples of rice bran and rice hull. Of the Aspergillus species, A. flavus and A. candidus were the most frequently isolated and 53\% strains of the A. flavus isolates were found to be toxigenic, producing only the group B aflatoxins.

A total of 37 fungal species were identified in common and dwarf cashew nuts (34). A. niger was the dominant species followed by A. flavus. P. brevicompactum and P. glabrum were the most frequently isolated penicillia. Higher contamination was found in dwarf kernels.

Forty-two species of field and storage fungi were isolated in black and white pepper (35). A. flavus and A. niger were encountered most frequently, prevalence being greater in the black pepper. Other potential mycotoxigenic species isolated were: A. ochraceus, $A$. tamarii, A. versicolor, Emericella nidulans, Chaetomium globosum, P. brevicompactum, P. citrinum, P. islandicum and P. glabrum.

Fusarium (68\%; main species, F. moniliforme), Aspergillus (58\%; main species, A.flavus) and Penicillium were the principal genera in 96 samples of cattle feedstuffs from São Paulo (21). Twenty of 26 A. flavus isolates were AFB producers. $\mathrm{AFB}_{1}$ and $\mathrm{AFB}_{2}$ were found in 14 samples. In 60 samples of poultry feedstuffs from Amazonas, northern Brazil, however, the major genera were Aspergillus (72\%), Rhizopus (28\%), Absidia (27\%), Penicillium (12\%), Mucor (12\%) and Fusarium (10\%). A. flavus was the most frequently isolated $A$. species, $44 \%$ of the strains being toxigenic, but AFs were not detected in the 60 samples.

In two cultivars of Brazilian apples, Gala and Fiji, inoculated with $P$. expansum NRRL 1172 or toxigenic $P$. variabile isolated from apples, and stored for 15 to 90 days at 0 to $25^{\circ} \mathrm{C}$, patulin production was negative until the $30^{\text {th }}$ day of storage at $0^{\circ} \mathrm{C}$ (103). Thereafter and under the other storage conditions, patulin was produced with both Penicillium strains.
Strains of Aspergillus and Penicillium were isolated from several samples of Brazilian cheese and their toxin producing potential was evaluated (120). Two of the isolated Penicillium species produced citrinin, while another produced patulin. None of the mycotoxins (AFs, OTA, PAT, penicillic acid, citrinin) analyzed, however, was detected in the samples.

Zearalenone production by Fusarium graminearum induced by the mutagenic agent nitrosoguanidine was also investigated in 40 samples differing from the control in morphological aspects, growth rates and pigmentation (60). Ten variants showed an increase in yield of 2 to 16 times, compared to the control.

\section{PREVENTION, CONTROL AND EFFECTS OF PROCESSING}

Efforts to find means of preventing or controlling fungal growth and mycotoxin production had received much greater attention in the decade focalized.

In the peanut variety "Tatu Vermelho", optimum production of aflatoxin occurred at $\mathrm{a}_{\mathrm{w}}$ of 0.93 ; at $\mathrm{a}_{\mathrm{w}} 0.86$ there was no formation of AF in 120 days (92). In beans inoculated with A. alutaceus Berk \& Curt, an ochratoxigenic strain, production of OTA and fungal growth were not observed even after 30 days of incubation at $\mathrm{a}_{\mathrm{w}}$ of $0.75 ;$ at $\mathrm{a}_{\mathrm{w}} 0.80$, OTA was detected after 20 days and at $\mathrm{a}_{\mathrm{w}} 0.84$, after 10 days (64). Maximum OTA production occurred at $\mathrm{a}_{\mathrm{w}} 0.90$.

The influence of $\mathrm{pH}$ and acids on the level of glucose needed to induce aflatoxin production was studied by Luchese and Harrigan (53). The results indicated that the major role of $\mathrm{pH}$ is related to the initial events of the synthesis. Hydrochloric acid and lactic acid had little effect. Glucose was found not to be a limiting factor for $\mathrm{AF}$ synthesis to occur.

Three varieties of corn inoculated with A. flavus NRRL 6513 were shown to be equally susceptible to fungal infection and $\mathrm{AFB}_{1}$ production (94). $\mathrm{AFB}_{1}$ production of four genotypes of peanuts (including the most planted in Brazil), inoculated with A. flavus IMI 190443 , was also investigated by Prado et al. $(89,99)$. The genotype 2117, originating from India, presented the lowest $\mathrm{AFB}_{1}$ levels, indicating varietal resistance as a possible means of control.

AFs were not detected in five samples of recently harvested peanut produced in places with sandy soil, while both $\mathrm{AFB}_{1}$ and $\mathrm{AFG}_{1}$ were produced in six of seven samples of the same peanut cultivar cultivated in places with clay soil, suggesting some influence of the type of soil on aflatoxin production (93).

In both the rainy seasons of 1990 and 1991, after storage for 80 and 30 days, respectively, the AF level was considerably lower in moist in-shell peanuts stored in jute bags than in those stored in polypropylene bags (30). There was a slightly better moisture loss in jute bags compared to polyethylene bags. Electronic color sorting was efficient in eliminating highly contaminated lots, directing them to rejected portions, although there was no obvious improvement in the overall initial contamination (130). The presence of A. flavus in corn enhanced growth of mites 
which, in turn, efficiently dispersed viable fungal spores from the inoculated to the uncontaminated compartments (33).

The antagonistic potential of some microorganisms against mycotoxin-producing fungi was also studied. Screening of 80 soil and corn samples yielded 51 microorganisms antagonistic to $F$. moniliforme $113 \mathrm{~F}$, of which 3 sporulated gram positive bacilli and 2 gram positive cocci showed the best antifungal activity $(68,69)$. Soil-isolated bacteria, with proven in vitro activity against $F$. moniliforme, were found more effective than four chemical fungicides (benomyl, triflumizole, perfurazoate, prochloraz) in controlling a fungal disease in rice plants (70). Of 150 isolates, attention was drawn to Bacillus spp. and a yeast, obtained from silage and corn, respectively, which showed intense proliferation and antifungal activity which impeded the growth of $F$. moniliforme (11). These three sporulated bacilli and yeast were subsequently shown to degrade $43-83 \%$ and $57 \%$, respectively, of the initial $\mathrm{FB}_{1}$ concentration in a corn culture inoculated with F. moniliforme (12).

Twenty-one isolates of yeasts from apple, with antagonistic activity against Penicillium spp., were assessed in terms of a detoxifying action against patulin (51). The best results were obtained with two isolates which reduced the patulin concentration by 85 and $75 \%$.

In line with natural control of phytopathogens, using amylase inhibitors, the amilases of Fusarium moniliforme and Aspergillus flavus were produced and characterized in terms of $\mathrm{pH}$ and temperature of maximum activity and stability (28). A culture medium containing starch, glycerol, wheat bran or corn and the respective starch or supernatant fraction was also evaluated (27). The medium with milky stage corn supernatant promoted the best mycelial growth while that with $2 \%$ ground corn in milky stage corn supernatant gave the highest amylase production.

Aluminum, iron and zinc added at $40-160 \mu \mathrm{g} / \mathrm{g}$ inhibited $\mathrm{AFB}_{1}$ production in autoclaved peanuts, inoculated with spores of $A$. flavus NRRL 6513 (87). Nickel at $4.0 \mu \mathrm{g} / \mathrm{g}$ stimulated $\mathrm{AFB}_{1}$ production but inhibited it at 1.0 and $2.0 \mu \mathrm{g} / \mathrm{g}$. However, iron applied as ferrous sulfate solution on the leaves (91) and in the soil (90) did not appear effective in lowering the $\mathrm{AFB}_{1}$ content of peanuts inoculated with A. flavus NRRL 5940 and IMI 190443, respectively.

Propionic acid (as ammonium propionate) sprayed on rehydrated (16-18\% moisture) inshell peanuts at $5 \mathrm{~g} / \mathrm{kg}$ was effective in controlling total and aflatoxigenic fungal growth and aflatoxin production during the entire evaluation period (28 days) $(9,10,102)$. At $3 \mathrm{~g} / \mathrm{kg}$, it was efficient only until 14 days. All other treatments (grapefruit seed extract at 5 and $10 \mathrm{~g} / \mathrm{kg}$, sodium orthophenylphenate at 2.5 and $5 \mathrm{~g} / \mathrm{kg}$, thiabendazole at 1 and $5 \mathrm{~g} / \mathrm{kg}$ ) were inefficient.

An initial study indicated that phosphine fumigation might affect the growth of A. flavus/A. parasiticus and AF production in peanuts stored in warehouses with moisture content above the recommended level (13). In a subsequent study, fumigation with phosphine ( 3 applications in 7 days) controlled fungal development and maintained AF levels in high-moisture (18-
$21 \%$ ) unshelled peanuts, while the untreated stacks showed staggering increase (14). After a month, however, no difference was observed in AF contamination and infection by A. flavus and $A$. parasiticus between the untreated and treated stacks.

Application of the fungicide iprodione in aqueous or oily solution reduced AF levels in corn stored in a ventilated atmosphere (86). Without ventilation, reduction of AF was not significant, especially at elevated moisture levels.

Sodium bentonite (110) and the synthetic zeolite NaA (62) were also shown to counteract some of the toxic effects of AF in growing broiler chicks.

Roasting of artificially contaminated peanuts in a microwave oven for 6 min decreased $\mathrm{AFB}_{1}$ and $\mathrm{AFG}_{1}$ by 41 to $70 \%$ (96). In Brazilian beans, previously inoculated with the ochratoxigenic strain A. alutaceus, cooking under pressure at $115^{\circ} \mathrm{C}$ for $45 \mathrm{~min}$ decreased OTA substantially (up to $84 \%$ ), especially when soaked in water for $12 \mathrm{~h}$ before cooking (65).

A patulin-producing Penicillium expansum strain, isolated from apples, was inoculated in sound apples and migration of patulin from the point of inoculation was studied (121). Trimming just the rotten tissue was not enough to exclude all patulin, but removal of $1 \mathrm{~cm}$ around the rotten tissue would be satisfactory, the toxin not being detected at this distance.

The effect of parboiling in rice (with bran), artificially contaminated with AF and naturally contaminated with OTA, was also assessed (20). Migration of $32 \% \mathrm{AFB}_{1}, 44 \% \mathrm{AFB}_{2}$, $36 \% \mathrm{AFG}_{1}, 21 \% \mathrm{AFB}_{2}$ and $66 \%$ OTA was observed.

Roasting with oil at $195^{\circ} \mathrm{C}$ and frying yielded nearly total destruction of Afs in naturally contaminated peanuts (115). Laboratory or industrial dry roasting at $130^{\circ} \mathrm{C}$ resulted in practically no destruction of AFs. Boiling in water or water with 5\% salt caused approximately $80 \%$ AF destruction. Thus, thermal treatment was found to be an adequate means of detoxifying naturally contaminated peanuts provided the temperature was kept at $195 \pm 5^{\circ} \mathrm{C}$.

Filtered juice of Agave sisalana leaves inhibited the growth of A. flavus, A. parasiticus and A. sp. in corn (84). The flavonoids quercetin, kaempherol, kaempheritrin and naringinin at 300, 100, 300 and $125 \mathrm{ppm}$ showed reductions of 36, 40, 49 and $60 \%$ of $A$. flavus growth in culture media (57). The greatest inhibition of $\mathrm{AFB}_{1}$ production (90\%) was seen with kaempheritrin at $100 \mathrm{ppm}$.

\section{TOXIC EFFECTS AND MODE OF ACTION}

The acute effects of a single intraperitoneal dose of $\mathrm{AFB}_{1}(60$ $\mathrm{mg} / \mathrm{kg}$ animal weight) on different inbred mouse strains were evaluated (2,3). Histopathologic lesions and biochemical changes differed with the different strains, probably reflecting the strains' ability to biotransform and eliminate $\mathrm{AFB}_{1}$ and its metabolites.

Citrinin inhibited the growth of three renal cells, i.e. $\mathrm{LLC}_{\mathrm{M}} \mathrm{MK}_{2}$, PK-15 and MDBK, especially in the first hours (129). The LLC$\mathrm{MK}_{2}$ cells decreased the most and the MDBK cells showed distinct 
morphological alterations. Studies on the mechanism of citrinininduced dysfunction of the rat mitochondria were undertaken (16-19). Citrinin depressed the phosphorylation efficiency of renal cortical mitochondria and inhibited most of the enzymes of the respiratory chain of the rat renal cortical and liver mitochondria. This mycotoxin also decreased the rate of mitochondrial swelling induced by the valinomycin- $\mathrm{K}^{+}$complex, suggesting its interference on the inner mitochondrial membrane fluidity.

The occurrence of five cases of equine leukoencephalomalacia associated with the ingestion of moldy corn during the winter of 1990 in São Paulo was reported, with detailed description of clinical signs and the results of histopathological examination (128). The clinical, etiologic and pathological diagnosis of an outbreak of equine leukoencephalomacia in Rio Grande do Sul was also described (56). Two samples of corn consumed by the affected horses contained $\mathrm{FB}_{1}\left(46\right.$ and $53 \mu \mathrm{g} / \mathrm{g}$ ) and $F$. moniliforme. $\mathrm{FB}_{1}$ $(0.2-38.5 \mu \mathrm{g} / \mathrm{g})$ and $\mathrm{FB}_{2}(0.1-12.0 \mu \mathrm{g} / \mathrm{g})$ were found in 20 and 18 samples, respectively, of $21 \mathrm{~F}$. moniliforme-contaminated feed samples from Paraná associated with outbreaks of confirmed and suspected mycotoxicoses in various animal species (114). With the exception of one, all $26 \mathrm{~F}$. moniliforme isolates from the feed samples were acutely toxic to ducklings and contained $\mathrm{FB}_{1}$ and $\mathrm{FB}_{2}$ at $65-4420$ and 5-1380 $\mu \mathrm{g} / \mathrm{g}$, respectively.

$\mathrm{AFB}_{1}, \mathrm{AFM}_{1}$ and aflatoxicol were not found in the liver, kidney or urine of calves intoxicated chronically, but detectable levels of $\mathrm{AFB}_{1}$ were found in tissues and urine of two calves that received single doses of 0.8 and $1.8 \mathrm{mg} \mathrm{AFB} / / \mathrm{kg}$ animal weight (107). The livers of laying hens exposed to $\mathrm{AFB}_{1}(100,300,500 \mu \mathrm{g} / \mathrm{kg}$ feed, for 60 days, 4 hens per group) appeared congested and showed signs of degeneration (77). Hepatic cell vacuolation with fatty infiltration were observed in all groups, including the control, but was more marked with increasing mycotoxin dose, being maximum in hens that received rations with $500 \mu \mathrm{g} / \mathrm{kg}$ of the toxin. Bile duct proliferation and trabecular disorder were seen in the livers of hens exposed to $\mathrm{AFB}_{1}$ at levels above $300 \mu \mathrm{g} / \mathrm{kg}$

$\mathrm{AFB}_{1}$ residues were determined in eggs of young laying hens fed with rations containing different levels of the mycotoxin $(0$, 100,300 or $500 \mu \mathrm{g} / \mathrm{kg}$ feed, for eight weeks, 24 birds for each group) and detected only in the eggs of hens given $500 \mu \mathrm{g} / \mathrm{kg}$ feed, at levels ranging from 0.05 to $0.16 \mu \mathrm{g} / \mathrm{kg}$ (76). The results indicated that the feed to egg $\mathrm{AFB}_{1}$ transmission ratio was about 5000:1.

In a preliminary study carried out to evaluate the incidence of hepatic diseases, especially hepatocellular carcinoma, in children and adults from the State of Santa Catarina from 1980 to 1998 , mycotoxin contamination of food was cited as one of the possible factors that could lead to these diseases (46).

The prominent signs of aflatoxicoses in several species, including mammals, are hypolipidaemia, hypocholesterolaemia and hypocarotenaemia, associated with severe hepatic steatosis and weight loss. It is suggested that these signs of acute imbalance of lipid metabolism can be the result of chemical modification of the LDL apoprotein by the activated $\mathrm{AFB}_{1}(5)$. Modified LDLs are not recognized by their specific receptors, and bind to liver cells. Lipid starvation of peripheral tissues takes place while fat accumulates in the liver. This abnormal state is maintained and reinforced by further modification of nascent apoproteins for as long as AF continues to be available to the liver.

\section{CONCLUDING REMARKS}

In spite of constraints in human and material resources, Brazilian researchers are responding to the needs of the country in confronting the mycotoxin problem. The research activities undertaken reflect current international concerns and recent developments in the area. Recognition of this work by government authorities involved in policy making is imperative to transform research results into practical applications.

\section{RESUMO}

\section{Pesquisa em micotoxinas no Brasil: a última década em foco}

O número de artigos de pesquisa (128 artigos) sobre micotoxinas publicados por pesquisadores brasileiros em 19912000 superou a soma de artigos (85 artigos) publicados nas três décadas anteriores (1961-1990). Trinta por cento das publicações foi levantamento da ocorrência de micotoxinas em alimentos e rações. Aflatoxinas em amendoim e produtos de amendoim continua sendo um problema alarmante, e a alta incidência e níveis elevados de fumonisinas em milho e produtos de milho também parecem ser um problema sério. A contaminação com outras micotoxinas, como zearalenona, ocratoxina A e tricotecenos, foi baixo. A ocorrência de aflatoxina $M_{1}$ em leite e laticínios e de patulina em suco de maçã precisa ser verificada, pois, há uma certa divergência nos resultados. Trabalhos sobre os métodos analíticos, estudos micológicos e efeitos tóxicos constituíram 16, 13 e 13\%, respectivamente, dos artigos publicados na década avaliada. A busca de meios de prevenção/controle da contaminação fúngica e produção de micotoxinas aumentou notadamente, perfazendo $27 \%$ dos artigos, incluindo investigações sobre fatores influentes (por exemplo, resistência de genótipos, conteúdo/atividade de água, umidade relativa, temperatura, presença de metais, tipo de solo, infestação com inseto) e o potencial antagônico de outros microrganismos contra os fungos produtores de micotoxinas. Os efeitos de extrato de planta, flavonóides, fungicidas e outros químicos, sacos utilizados para estocagem, adsorventes e processamento de alimentos foram também estudados. Portanto, apesar das limitações de recursos, a pesquisa brasileira responde as necessidades do país, reflete as preocupações internacionais e os desenvolvimentos recentes na área.

Palavras-chave: micotoxinas, ocorrência, fatores influentes, pesquisa, Brasil 


\section{REFERENCES}

1. Almeida, A.P.; Corrêa, B.; Mallozzi, M.A.B.; Sawazaki, E.; Valente Soares, L.M. Mycoflora and aflatoxin/fumonisin production by fungal isolates from freshly harvested corn hybrids. Braz. J. Microbiol., 31: 321-326, 2000.

2. Almeida, R.M.A.; Corrêa, B.; Malozzi, M.A.B.; Xavier, J.G.; Gambale, W.; Paula, C.R. Acute effect of aflatoxin $B_{1}$ on inbred strains of mice - I. Rev. de Microbiol., 26: 73-78, 1995.

3. Almeida, R.M.A.; Corrêa, B.; Xavier, J.G.; Mallozzi, M.A.B.; Gambale, W.; Paula, C.R. Acute effect of aflatoxin $\mathrm{B}_{1}$ on different inbred mouse strains II. Mycopathol., 133: 23-29, 1996.

4. Almeida, R.M.A.; Gambale, W.; Correa, B.; Paula, C.R.; Asevedo, I.G. Mycoflora and aflatoxigenic species of Aspergillus spp. isolated from rice. Rev. Microbiol., 22: 161-163, 1991.

5. Amaya-Farfan, J. Aflatoxin $B_{1}$-induced hepatic steatosis: role of carbonyl compounds and active diols on steatogenesis. Lancet, 353: 747-748, 1999.

6. Araújo, A.C.P.; Telles, D.L.; Graças-Almeida, M.; Nascimento, E.S. Determinación de aflatoxinas en cacahuetes comercilizados en RecifePE, Brasil. Alimentaria, 249: 35-37, 1994.

7. Asevedo, I.G.; Gambale, W.; Correa, B.; Paula, C.R.; Almeida, R.M.A.; Souza, V.M. Mycoflora and aflatoxigenic species of Aspergillus spp. isolated from stored maize. Rev. Microbiol., 25: 46-50, 1994.

8. Brigido, B.M.; Badolato, M.I.C.; Freitas, V.P.S. Contaminação de amendoim e seus produtos comercializados na região de Campinas SP., por aflatoxinas durante o ano de 1994. Rev. Inst. Adolfo Lutz, 55: 85-90, 1995.

9. Calori-Domingues, M.A.; Fonseca, H. Laboratory evaluation of chemical control of aflatoxin production in unshelled peanuts (Arachis hypogaea L.). Food Addit. Contam., 12: 347-350, 1995

10. Calori-Domingues, M.A.; Fonseca, H.; Ranzani, M.R.T.C. Effect of propionic acid on fungal growth and aflatoxin production in moist inshell groundnuts. Rev. Microbiol., 27: 71-77, 1996.

11. Camilo, S.B.; Oda, P.; Ono, C.J.; Muller, E.E.; Hirooka, E.Y. Ecossistema de milho e ensilagem no biocontrole de Fusarium moniliforme. Rev. Ciênc. Farm., 20: 143-154, 1999.

12. Camilo, S.B.; Ono, C.J.; Ueno, Y.; Hirooka, E.Y. Anti-Fusarium moniliforme activity and fumonisin biodegradation by corn and silage microflora. Braz. Arch. Biol. Tecnol., 43: 159-164, 2000.

13. Castro, M.F.P.M.; Pacheco, I.A.; Valente Soares, L.M.; Furlani, R.P.Z. Phosphine fumigation of stored in-shell peanuts for the control of A. flavus Link/A. parasiticus Speare growth and aflatoxin production. Rev. Microbiol., 26: 296-301, 1995.

14. Castro, M.F.P.P.M.; Pacheco, I.A.; Valente Soares, L.M.; Furlani, R.P.Z.; Paula, D.C.; Bolonhezi, S. Warehouse control of Aspergillus flavus Link and A. parasiticus Speare on peanuts (Arachis hypogaea) by phosphine fumigation and its effect on aflatoxin production. $J$. Food Prot., 59: 407-411, 1996.

15. Castro, M.F.P.M.; Valente Soares, L.M.; Furlani, R.P.Z. Mycoflora, aflatoxigenic species and mycotoxins in freshly harvested corn (Zea mays L.): A preliminary study. Rev. Microbiol., 26: 289-295, 1995.

16. Chagas, G.M.; Campello, A.P.; Klüppel, M.L.W. Mechanism of citrinin-induced dysfunctionof mitochondria I. Effects on respiration, enzyme activities and membrane potential of renal cortical mitochondria. J. Appl. Toxicol., 12: 123-129, 1992.

17. Chagas, G.M.; Oliveira, M.B.M.; Campello, A.P.; Klüppel, M.L.W. Mechanism of citrinin-induced dysfunction of mitochondria II. Effect on respiration, enzyme activities and membrane potential of liver mitochondria. Cell. Biochem. Funct., 10: 209-216, 1992.

18. Chagas, G.M.; Oliveira, M.B.M.; Campello, A.P.; Klüppel, M.L.W. Mechanism of citrinin-induced dysfunction of the mitochondria III. Effects on renal cortical and liver mitochondrial swelling. J. Appl. Toxicol., 15: 91-95, 1995.

19. Chagas, G.M.; Oliveira, M.B.M.; Campello, A.P.; Kluppel, M.L.W. Mechanism of citrinin-induced dysfunction of mitochondria. IV. Effect on Ca super(2+) transport. Cell. Biochem. Funct., 13: 53-59, 1995.

20. Coelho, C.S.P.; Furlong, E.B.; Almeida, T.L. Mycotoxin migration during the parboiling of rice. Braz. J. Food Technol., 2: 39-44, 1999.
21. Corrêa, B.; Galhardo, M.; Costa, E.O.; Sabino, M. Distribution of molds and aflatoxins in dairy cattle feeds and raw milk. Rev. Microbiol., 28: 279-283, 1997.

22. Côrtes, N.A.; Cassetori, D. Neto; Corrêa, B. Ocorrência de aflatoxinas em milho produzido pelo sistema tradicional de cultivo, em comunidades de agricultura familiar, no estado de Mato Grosso. Higiene Alimentar, 14: 16-26, 2000.

23. Dias, S.M.C.; Mallozzi, M.A.B.; Corrêa, B.; Israel, W.M.; Gonzalez, E. Fluorimetric quantitation of OPA-derivatives of fumonisins $B_{1}$ and $\mathrm{B}_{2}$ in corn and Fusarium moniliforme culture extracts. Arq. Inst. Biol., 66: 69-75, 1999.

24. Dilkin, P.; Mallman, C.A.; Santurio, J.M.; Hickmann, J.L. Classificação macroscopica, identificação da microbiota fúngica e produção de aflatoxinas em híbridos de milho. Ciênc. Rural, 30: 137-141, 2000.

25. Duarte, R.R.; Carvalho, E.C.Q.; Rosa, C.A.R. Aflatoxina em fígados de frangos de corte, com esteatose, abatidos industrialmente no Estado de Rio de Janeiro. Rev. Brás. Ciênc. Vet., 4: 117-120, 1997.

26. Figueira, A.C.; Taylor, K.D.A.; Barlow, P.J.; Morgan, M.R.A. Anomalous aflatoxin 1 recoveries from whole peanuts and Brazil nuts measured by enzyme-linked immunosorbent assay. Food Agric. Immunol., 3: 13-19, 1991.

27. Figueira, E.L.Z;; Hirooka, E.Y. Culture medium for amylase production by toxigenic fungi. Braz. Arch. Biol. Technol., 43: 461-467, 2000.

28. Figueira, E.L.Z.; Sá, M.C.; Ida, E.I.; Hirooka, E.Y. Produção e caracterização de amilase de Fusarium moniliforme e Aspergillus flavus. Rev. CEPPA, 18: 13-26, 2000

29. Fonseca, H. Sistema de amostragem para análise de aflatoxinas em grãos. Rev. Microbiol., 21: 66-70, 1991.

30. Fonseca, H.; Calori-Domingues, M.A.; Glória, E.M.; Luiz Neto, M.; Zambello, I.V. Influence of bag materials on the moisture loss and final aflatoxin content of in-shell peanuts stored moist. First studies. Food Addit. Contam., 12: 337-341, 1995.

31. Fonseca, H.; Valarini, I.; Domingues, M.A.C.; Wettstein, A.S.R.; Silva, A.E.G. Ocorrência de aflatoxina em amendoim, no Estado de São Paulo, durante os anos de 1988-1989. Anais ESALQ, 48: 301-316, 1991.

32. Fraga, M.E.; Direito, G.M.; Santana, D.M.N.; Barros, G.C.; Rosa, C.A.R. Determinação por cromatografia em camada delgada de aflatoxinas $\left(\mathrm{B}_{1}\right.$ e $\left.\mathrm{M}_{1}\right)$ e aflatoxicol em ovos destinados ao comércio. Rev. Brás. Méd. Vet., 18: 172-175, 1996.

33. Franzolin, M.R.; Gambale, W.; Cuero, R.G.; Correa, B. Interaction between toxigenic Aspergillus flavus Link and mites (Tyrophagus putrescentiae Schrank) on maize grains: effects on fungal growth and aflatoxin production. J. Stored Prod. Res., 35: 215-224, 1999

34. Freire, F.C.O.; Kozakiewicz, Z.; Paterson, R.R.M. Mycoflora and mycotoxins of Brazilian cashew kernels. Mycopathol., 145: 95-103, 1999.

35. Freire, F.C.O.; Kozakiewicz, Z.; Paterson, R.R.M. Mycoflora and mycotoxins in Brazilian black pepper, white pepper and Brazil nuts. Mycopathol., 149: 13-19, 2000.

36. Freitas, V.P.S.; Badolato, M.I.C. Incidência de aflatoxinas em paçocas de amendoim consumidas na cidade de Campinas, estado de São Paulo. Rev. Inst. Adolfo Lutz, 52: 83-87, 1992.

37. Freitas, V.P.S.; Brigido, B.M. Occurrence of aflatoxins $B_{1}, B_{2}, G_{1}$, and $\mathrm{G}_{2}$ in peanuts and their products marketed in the region of Campinas, Brazil in 1995 and 1996. Food Addit. Contam., 15: 807-811, 1998

38. Furlani, R.P.Z.; Soares, L.M.V. Survey of aflatoxins, ochratoxin A zearalenone, and sterigmatocystin in tree nuts commercialized in Campinas, São Paulo. Ciênc. Tecnol. Aliment., 16: 238-240, 1996.

39. Furlong, E.B.; Soares, L.A.S.; Vieira, A.P.; Dadalt, G. Aflatoxinas, ocratoxina A e zearalenona em alimentos da região do Rio Grande do Sul. Rev. Inst. Adolfo Lutz, 58: 105-111, 1999.

40. Furlong, E.B.; Valente Soares, L.M. Gas chromatographic method for quantitation and confirmation of trichotecenes in wheat. J. AOAC Inter., 78: 386-390, 1995.

41. Furlong, E.B.; Valente Soares, L.M.; Lasca, C.C.; Kohara, E.Y. Mycotoxins and fungi in wheat stored in elevators in the state of Rio Grande do Sul, Brazil. Food Addit. Contam., 12: 683-688, 1995.

42. Furlong, E.B.; Valente Soares, L.M.; Lasca, C.C.; Kohara, E.Y Mycotoxins and fungi in wheat harvested during 1990 in test plots in the state of São Paulo, Brazil. Mycopathol., 131: 185-190, 1995. 
43. Glória, E.M.; Fonseca, H.; Souza, I.M. Occurrence of mycotoxins in maize delivered to the food industry in Brazil. Trop. Sci., 37: 107$110,1997$.

44. Glória, E.M.; Fonseca, H.; Calori-Domingues, M.A.; Souza, I.M. Evaluation of the black light test for screening aflatoxincontaminated maize in the Brazilian food industry. Food Addit. Contam., 15: 181-184, 1998.

45. Gonçalves, C.M.R.; Fonseca, H. Ocorrência de aflatoxinas em farelo de algodão (Gossypium hirsutum L.) na safra de 1986. Anais ESALQ, 48: 317-333, 1991

46. Haas, P.; Scussel, V.M. Heptacellular carcinoma and other hepatic diseases in Santa Catarina State. Proceedings of the International Symposium of Mycotoxicology'99, Chiba, Japan, 1999, p.231-235.

47. Hennigen, M.R.; Dick, T. Incidence and abundance of mycotoxins in maize in Rio Grande do Sul, Brazil. Food Addit. Contam., 12: 677-681, 1995 .

48. Hirooka, E.Y.; Yamaguchi, M.M.; Aoyama, S.; Sugiura, Y.; Ueno, Y. The natural occurrence of fumonisins in Brazilian corn kernels. Food Addit. Contam., 13: 173-183, 1996.

49. Jarvis, B.B.; Mokhtari-Rejali, N.; Schenkel, E.P.; Barros, C.S.; Matzenbacher, N.I. Trichothecene mycotoxins from Brazilian Baccharis species. Phytochem., 30: 789-797, 1991.

50. Leoni, L.A.B.; Valente Soares, L.M.; Oleiveira, P.L.C. Ochratoxin A in Brazilian roasted and instant coffees. Food Addit. Contam., 17: 867-870, 2000.

51. Levy, R.M.; Hirooka, E.Y. Detoxificação de patulina por leveduras antagonistas a Penicillium spp. UNOPAR Cien. Ciênc.Biol. Saúde, 1: 57-62, 1999.

52. Lima, C.A.P.; Orsi, R.B.; Dilkin, P.; Corrêa, B. Mycoflora and aflatoxigenic species in derivatives of milled rice. Cienc. Tecnol. Aliment., 20: 37-39, 2000.

53. Luchese, R.H.; Harrigan, W.F. Influence of $\mathrm{pH}$ and lactic acid on the levels of glucose needed to induce aflatoxin production in Aspergillus parasiticus. Lebens.-Wissen.u.-Technol., 26: 242-250, 1993.

54. Machinski, M. Jr.; Midio, A.F. Incidencia de patulina en jugo de manzana industrializado. Alimentaria, 276: 61-64, 1996.

55. Machinski, M. Jr.; Valente Soares, L.M. Fumonisins $B_{1}$ and $B_{2}$ in Brazilian corn-based food products. Food Addit. Contam., 17: 875-879, 2000.

56. Mallman. C.A.; Santurio, J.M.; Dilkin, P. Equine leukoencephalomalacia associated with ingestion of corn contaminated with fumonisin $\mathrm{B}_{1}$. Rev. Microbiol., 30: 249-252, 1999b.

57. Mallozzi, M.A.B.; Corrêa, B.; Haraguchi, M.; Brignani Neto, F. Effect of flavonoids on Aspergillus flavus growth and aflatoxin production. Rev. Microbiol., 27: 161-165, 1996.

58. Marochi, M.A.; Valente Soares, L.M. Metodologia para determinação de tricotecenos e zearalenona em grãos. Bol. Soc. Brás. Ciênc. Tecnol. Aliment., 27: 1-8, 1993.

59. Marochi, M.A.; Soares, L.M.V.; Furlani, R.P.Z. Testes confirmatórios para tricotecenos. Rev. Inst. Adolfo Lutz, 56: 17-20, 1996.

60. Martins, E.R.; Kemmelmeier, C. Zearalenone production in Fusarium graminearum variants after treatment with nitrosoguanidine. Rev. Microbiol., 24: 248-254, 1993.

61. Martins-Maciel, E.R.; Machinski, M. Jr.; Pereira, S.R.C.; Takahachi, G.; Kemmelmeier, C.; Nishiyama, P. Incidence of aflatoxins and Aspergillus flavus in peanuts consumed in Maringá City, Brazil. Arq. Biol. Tecnol., 39: 807-813, 1996.

62. Miazzo, R.; Rosa, C.A.R.; Queiroz Carvalho, E.C.; Magnoli, C.; Chiacchiera, S.M.; Palacio, G.; Saenz, M.; Kikot, A.; Basaldella, E.; Dalcero, A. Efficacy of synthetic zeolite to reduce the toxicity of aflatoxin in broiler chicks. Poult. Sci., 79: 1-6, 2000.

63. Milanez, T.V.; Atui, M.B.; Lazzari, F.A. Comparação entre imunoensaio e cromatografia em camada delgada na determinação de aflatoxinas, ocratoxina A e zearalenona em amostras de milho em grão e fuba. Rev. Inst. Adolfo Lutz, 57: 65-71, 1998.

64. Milanez, T.V.; Leitão, M.F.F. Atividade de água na produção de ocratoxina A por Aspergillus alutaceus Berk \& Curt em feijão. Ciênc. Tecnol. Aliment., 14: 238-246, 1994.

65. Milanez, T.V.; Leitão, M.F.F. The effect of cooking on ochratoxin A content of beans, variety "Carioca". Food Addit. Contam., 13: 89-93, 1996.

66. Milanez, T.V.; Sabino, M.; Lamardo, L.C.A. Comparison of two methods for the determination of ochratoxin A in green coffee beans. Rev. Microbiol., 26: 79-82, 1995.
67. Motomura, M.; Hirooka, E.Y. Método rápido para o isolamento de microrganismos de solo com atividade antifúngica sobre Fusarium moniliforme. Arq. Biol. Tecnol., 39: 313-322, 1996.

68. Motomura, M.; Hirooka, E.Y. Microrganismos produtores de substâncias antifúngicas com perspectivas para aplicação no controle de Fusarium moniliforme. Arq. Biol. Tecnol., 39: 471-479, 1996.

69. Motomura, M.; Lourenço, C.E.; Venturini, D.; Ueno, Y.; Hirooka, E.Y. Screening and isolation of anti-Fusarium moniliforme compounds producing microorganisms from soil and corn. Rev. Microbiol., 27: 213-217, 1996.

70. Motomura, M.; Suwa, S.; Hirooka, E.Y. Biological control: Microbial versus chemical fungicide on growth of rice infected with Fusarium moniliforme. Rev. Microbiol., 28: 11-16, 1997.

71. Motta, S.; Valente Soares, L.M. Simultaneous determination of tenuazonic and cyclopiazonic acids in tomato products. Food Chem., 71: 111-116, 2000.

72. Nicácio, M.A.S.; Prado, G.; Linardi, V.R. Determinação de aflatoxina e identificação da microbiota fúngica em milho (Zea mays L.) póscolheita. Arq. Biol. Tecnol., 38: 851-857, 1995.

73. Nordin, N.; Luchese, R.H. Detecção de aflatoxina e zearalenona em milho (Zea mays), destinado à alimentação animal. Bol. Soc. Brás. Ciênc. Tecnol. Aliment., 32: 35-39, 1998.

74. Oliveira, C.A.F.; Germano, P.M.L. Avaliação do desempenho do método do ensaio por enzimas imuno-adsorvidas (ELISA) em leite em pó reconstituído contaminado experimentalmente com aflatoxina $\mathrm{M}_{1}$. Rev. Saúde Pública, 30: 542-548, 1996.

75. Oliveira, C.A.F.; Germano, P.M.L.; Bird, C.; Pinto, C.A. Immunochemical assessment of aflatoxin $\mathbf{M}_{1}$ in milk powder consumed by infants in São Paulo, Brazil. Food Addit. Contam., 14: 7-10, 1997.

76. Oliveira, C.A.F.; Kobashigawa, E.; Reis T.A.; Mestieri, L.; Albuquerque, R.; Corrêa, B. Aflatoxin $\mathrm{B}_{1}$ residues in eggs of laying hens fed a diet containing different levels of the mycotoxin. Food Addit. Contam., 17: 459-462, 2000.

77. Oliveira, C.A.F.; Reis, T.A.; Albuquerque, R.; Guerra, J.L.; Correa, B. Hepatic lesions in laying hens chronically exposed to rations containing different levels of aflatoxin $\mathrm{B}_{1}$. Arq. Inst. Biol. 66: 39-43, 1999.

78. Oliveira, J.A.A.; Corrêa, B.; Castrillón, A.L.; Cortez, A.C.A. Occurrence of filamentous fungi and aflatoxins in poultry feedstuffs. Rev. Microbiol., 29: 138-142, 1998.

79. Oliveira, V.; Mesquita, A.J.; Bisol-Serafini, A.; Ribeiro, J.L.; Silva, M.R.R. Ocorrência de aflatoxinas $\mathrm{B}_{1}$ e $\mathrm{G}_{1}$ em amendoim comercializado em Goiânia-GO, Brasil. Rev. Microbiol., 22: 319-322, 1991.

80. Ono, E.Y.S.; Kawamura, O.; Ono, M.A.; Ueno, Y.; Hirooka, E.Y. A comparative study of indirect competitive ELISA and HPLC for fumonisin detection in corn of state of Paraná, Brazil. Food Agric. Immunol., 12: 5-14, 2000.

81. Ono, E.Y.S.; Sugiura, Y.; Homechin, M.; Kamogae, M.; Vizzoni, E.; Ueno, Y.; Hirooka, E.Y. Effect of climatic conditions on natural mycoflora and fumonisins in freshly harvested corn of the state of Parana, Brazil. Mycopathol., 147: 139-148, 1999.

82. Orsi, R.B.; Correa, B.; Possi, C.R.; Schammas, E.A.; Nogueira, J.R.; Dias, S.M.C.; Malozzi, M.A.B. Mycoflora and occurrence of fumonisins in freshly harvested and stored hybrid maize. J. Stored Prod. Res., 36: 75-87, 2000.

83. Palomino, M.E.T.; Fonseca, H.; Glória, E.M.; Calori-Domingues, M.A.; Marques, C. Avaliação do método de triagem para análise de milho contaminado com aflatoxinas pela fluorescência amareloesverdeada brilhante (BGYF-Bright Greenish Yellow Fluorescence). Sci. Agric., 55: 503-508, 1998.

84. Pires, M.F.C.; Purchio, A. Mycological evaluation of filtrated juice of Agave sisalana Perrine's leaf. Rev. Microbiol., 22: 272-275, 1991.

85. Pozzi, C.R.; Corrêa, B.; Gambale, W.; Paula, C.R.; Chacon-Reche, N.O.; Meirelles, M.C.A. Postharvest and stored corn in Brazil: mycoflora interaction, abiotic factors and mycotoxin occurrence. Food Addit. Contam., 12: 313-319, 1995.

86. Prado, G.; Almeida Pinto, N.J.; Oliveira, M.S. Incidência de aflatoxinas em milho (Zea mays L.) com diferentes níveis de umidade, após tratamento com fungicida, armazenado em atmosfera com e sem aeração. Rev. Inst. Adolfo Lutz, 55: 79-84, 1995.

87. Prado, G.; Alvarez Leite, E.M.; Martins Vieira, M.B.; Oliveira, M.S. Influência de metais na produção de aflatoxina $\mathrm{B}_{1}$ em amendoim (Arachis hypogaea L.). Ciênc. Tecnol. Aliment., 15: 294-297, 1995. 
88. Prado, G.; Alvarez-Leite, E.M.; Martins Vieira, M.B.; Oliveira, M.S Standardization of a method for the inoculation of peanuts (Arachis hypogaea L) - Tatu Vermelho variety with Aspergillus flavus NRRL 6513, an aflatoxin $\mathrm{B}_{1}$ producer. Rev. Microbiol. 27: 203-207, 1996.

89. Prado, G.; Godoy, I.J.; Oliveira, M.S.; Gazzinelli-Madeira, J.E.; Junqueira, R.G.; Ferreira, S.O. Teste preliminar de resistência de dois genótipos de amendoim, 2117 e Tatu Vermelho, com relação à produção de aflatoxina $\mathrm{B}_{1}$ por uma espécie toxigênica de Aspergillus flavus Link. Rev. Inst. Adolfo Lutz, 56: 71-74, 1996.

90. Prado, G.; Godoy, I.J.; Oliveira, M.S.; Junqueira, R.G.; GazzinelliMadeira, J.E.C. Efeito do ferro na biossíntese de aflatoxina $\mathrm{B}_{1}$ por Aspergillus flavus IMI 190443 após inoculação em dois genótipos de amendoim. Rev. Inst. Adolfo Lutz, 57: 35-39, 1998.

91. Prado, G.; Godoy, I.J.; Oliveira, M.S.; Martins Vieira, M.B.C.; Cardoso, M.B. Influência de ferro na biossíntese de aflatoxina $\mathrm{B}_{1}$ pelo Aspergillus flavus NRRL 5940 em amendoim (Arachis hypogaea L.) variedades Tatu Vermelho e VRR-245. Ciênc. Tecnol. Aliment., 16: 22-25, 1996.

92. Prado, G.; Martin Vieira, M.B.C.; Nicasio, M.A.S.; Gloria, M.B.A. Efeito da umidade relativa na contaminação microbiana e produção de aflatoxinas em amendoim em grão. Ciênc. Tecnol. Aliment., 11: 264-273, 1991.

93. Prado, G.; Martins Vieira, M.B.C.; Oliveira, M.S. Contaminação fúngica e níveis de aflatoxinas em amendoim recém-colhido cultivado em dois tipos de solo. Ciênc. Tecnol. Aliment., 16: 72-74, 1996.

94. Prado, G.; Martins Vieira, M.B.C.; Santos, J.P.; Oliveira, M.S. Produção de aflatoxina $\mathrm{B}_{1}$ pelo Aspergillus flavus NRRL $6513 \mathrm{em}$ três variedades de milho (Zea mays L.). Ciênc. Tecnol. Aliment., 13: 226-230, 1993.

95. Prado, G.; Martins Vieira, M.B.C.; Santos, J.P.; Oliveira, M.S Ocorrência de micotoxinas em milho pós-colheita e armazenado do estado de Minas Gerais, safra 1991. Higiene Aliment., 9: 24-27, 1995.

96. Prado, G.; Oliveira, M.S. Efeito do forno de microondas na destruição de aflatoxinas em amendoim. Rev. Inst. Adolfo Lutz, 56: 21-24, 1996.

97. Prado, G.; Oliveira, M.S.; Abrantes, F.M.; Santos, L.G.; Veloso, T.; Barroso, R.E.S. Incidência de ocratoxina A em café torrado e moído e em café solúvel consumido na cidade de Belo Horizonte, MG. Cienc. Tecnol. Aliment., 20: 192-196, 2000.

98. Prado, G.; Oliveira, M.S.; Ferreira, S.O.; Corrêa, T.B.S.; Affonso, B.R.R. Ocorrência natural de desoxinivalenol e toxina T-2 em milho pós-colheita. Ciênc. Tecnol. Aliment., 17: 259-262, 1997.

99. Prado, G.; Oliveira, M.S.; Gazzinelli-Madeira, J.E.C.; Godoy, I.J.; Corrêa, B.; Junqueira, R.G.; Ferreira, S.O. Resistência de quatro genótipos de amendoim à produção de aflatoxina $\mathrm{B}_{1}$ após inoculação com Aspergillus flavus Link. Ciênc. Tecnol. Aliment., 19: 84-87, 1999.

100. Prado, G.; Oliveira, M.S.; Pereira, M.L.; Abrantes, F.M.; Santos, L.G.; Veloso, T. Aflatoxin $\mathrm{M}_{1}$ in samples of "Minas" cheese commercialized in the city of Belo Horizonte, Minas/Brazil. Ciênc. Tecnol. Aliment., 20: 398-400, 2000

101. Preis, R.A.; Vargas, E.A. A method for determining fumonisin $B_{1}$ in corn using immunoaffinity column clean-up and thin layer chromatography/ densitometry. Food Addit. Contam., 17: 463-468, 2000.

102. Ranzani, M.R.T.C.; Fonseca, H. Mycological evaluation of chemically treated unshelled peanuts. Food Addit. Contam., 12: 343-346, 1995.

103. Ross, G.U.; Taniwaki, M.H.; Sabino, M.; Vizoni, T.; Hirooka, E.Y., 1998. Produção de patulina em maça (Malus domestica Borkhausen), cultivares Gala e Fuji, inoculadas com Penicillium spp. Ciênc. Tecnol. Aliment., 18: 63-67, 1998.

104. Sabino, M.; Inomata, E.I.; Lamardo, L.C.A.; Milanez, T.V.; Navas, S.A.; Zorzetto, M.A.P. A survey of the occurrence of aflatoxins in groundnuts (peanuts) and groundnut products in São Paulo state/ Brazil in 1994. Rev. Inst. Adolfo Lutz, 58: 53-57, 1999.

105. Sabino, M.; Milanez, T.V.; Lamardo, L.C.A.; Inomata, E.I.; Zorzetto, M.A.P.; Navas, S.A.; Stofer, M. Occurrence of aflatoxins in peanuts and peanut products consumed in the state of São Paulo/Brazil from 1995 to 1997. Rev. Microbiol., 30: 85-88, 1999.

106. Sabino, M.; Milanez, T.V.; Lamardo, L.C.A.; Navas, S.A.; Stofer, M.; Garcia, C.B. Avaliação da eficiência de dois kits comerciais para detecção de aflatoxina $\mathrm{B}_{1}$ em amostras de milho, ração e amendoim e seus produtos. Ciênc. Tecnol. Aliment., 17: 107-110, 1997.

107. Sabino, M.; Purchio, A.; Milanez, T.V. Aflatoxins $B_{1}, M_{1}$ and aflatoxicol in tissues and urine of calves receiving aflatoxin. Food Addit. Contam., 12: 467-472, 1995.

108. Sabino, M.; Purchio, A.; Milanez, T.V. Survey of aflatoxin $B_{1}, M_{1}$ and aflatoxicol in poultry and swine tissues from farms located in the states of Rio Grande do Sul and Santa Catarina, Brazil. Rev. Microbiol., 27: 189-191, 1996.

109. Sabino, M.; Rodriguez-Amaya, D.B. Mycotoxin research in Brazil Ciênc. Cult., 45: 359-371, 1993.

110. Santurio, J.M.; Mallman, C.A.; Rosa, A.; Appel, G. Herr; Dageforde, S.; Boottcher, M. Effect of sodium bentonite on the performance and blood parameters of broiler chickens intoxicated with aflatoxins. Brit. Poult. Sci., 40: 115-119, 1999.

111. Scussel, V.M.; Costa, L.L.F.; Souza, G.D. Aflatoxins in raw and processed peanuts commercialized in Santa Catarina State, Brazil Proceedings of the International Symposium of Mycotoxicology'99, Chiba, Japan, p.220-225, 1999.

112. Silva, J.B.; Pozzi, C.R.; Mallozzi, M.A.B.; Ortega, E.M.; Corrêa, B. Mycoflora and occurrence of aflatoxin $\mathrm{B}_{1}$ and fumonisin $\mathrm{B}_{1}$ during storage of Brazilian sorghum. J. Agric. Food Chem., 48: 4352-4356, 2000

113. Silva, S.C.; Oliveira, J. N.; Caldas, E.D. Aflatoxinas em alimentos comercializados no Distrito Federal de 1985 a 1995. Rev. Inst. Adolfo Lutz, 56: 49-52, 1996.

114.Sydenham, E.W.; Marasas, W.F.O.; Shephard, G.S.; Thiel, P.G.; Hirroka, E.Y. Fumonisin concentrations in Brazilian feeds associated with field outbreaks of confirmed and suspected animal mycotoxicoses. J. Agric. Food Chem., 40: 994-997, 1992.

115. Sylos, C.M.; Amaya-Farfan, J. Aflatoxin destruction during heat processing of contaminated peanuts. A reevaluation. Bol. Soc. Brás. Ciênc. Tecnol. Aliment., 26: 89-96, 1992.

116. Sylos, C.M.; Rodriguez-Amaya, D.B. Estudo comparativo de métodos para determinação de aflatoxina $\mathbf{M}_{1}$. Rev. Inst. Adolfo Lutz, 56: 87-97, 1996.

117. Sylos, C.M.; Rodriguez-Amaya, D.B. Incidence of patulin in fruits and fruit juices marketed in Campinas, Brazil. Food Addit. Contam., 16: 71-74, 1999 .

118. Sylos, C.M.; Rodriguez-Amaya, D.B.; Carvalho, P.R.N. Occurrence of aflatoxin $\mathrm{M}_{1}$ in milk and dairy products commercialized in Campinas, Brazil. Food Addit. Contam., 13: 169-172 1996.

119. Sylos, C.M.; Rodriguez-Amaya, D.B.; Pinto, C.A.P.A. Comparação de imunodosagem e cromatografia em minicolunas para triagem de aflatoxinas em amendoim e milho. Aliment. Nutr. 7: 7-14, 1996.

120. Taniwaki, M.H.; van Dender, A.G.F. Occurrence of toxigenic molds in Brazilian cheese. J. Food Prot., 55:187-191, 1992

121. Taniwaki, M.H.; Hoenderboom, C.J.M.; Almeida-Vitali, A.; Uboldi-Eiroa, M.E. Migration of patulin in apples. J. Food Prot., 55: 902-904, 1992.

122. Valente Soares, L.M.; Furlani, R.P.Z. Survey of mycotoxins in whea and wheat products sold in health food stores of the city of Campinas, state of São Paulo. Rev. Microbiol., 27: 41-45, 1996.

123. Valente Soares, L.M.; Furlani, R.P.Z. Survey of aflatoxins, ochratoxin A, zearalenone and sterigmatocystin in health foods and breakfas cereals commercialized in the city of Campinas, São Paulo. Ciênc. Tecnol. Aliment., 16: 126-129, 1996.

124. Valente Soares, L.M.; Furlani, R.P.Z.; Oliveira, P.L.C. Species related differences in Brazilian green coffee contamination by ochratoxin A. In: Sera, T.; Soccol, C.R.; Pandey, A.; Roussos, S. (eds). Coffee Biotechnology and Quality, Kluwer Academic Publishers, Dordrecht, Holanda, 2000, p.369-376.

125. Valente Soares, L.M.; Rodriguez-Amaya, D.B. A survey of aflatoxins, ochratoxin A, zearalenone, and sterigmatocystin in some Brazilian foods by using multi-toxin thin layer chromatographic method. $J$. Assoc. Off. Anal. Chem., 72: 22-26, 1989.

126. Vicente, E.; Valente Soares, L.M. A thin layer chromatographic method for the determination of aflatoxins $\mathrm{B}_{1}$ and $\mathrm{M}_{1}$ zearalenone and ochratoxin A in animal tissues. Ciênc. Tecnol. Aliment. 15: 201-205, 1995.

127. Viera, A.P.; Badiale-Furlong, E.; Oliveira, M.L.M. Ocorrência de micotoxinas e caracteristicas físico-químicas em farinhas comerciais. Ciênc. Tecnol. Aliment., 19: 221-225, 1999.

128. Xavier, J.G.; Brunner, C.H.M.; Sakamoto, M.; Corrêa, B.; Fernandes, W.R.; Dias, J.L.C. Equine leukoencephalomalacia. Report of five cases. Braz. J. Vet. Res. Anim. Sci., 28: 185-189, 1991.

129. Yakamura, A.A.M.; Lograta, M.H.; Cruz, L.C.H.; Rocha, C.A.R Estudo da cinética do crescimento celular em culturas de células renais tratadas com citrinina. Semina, 12: 9-13, 1991.

130.Zovico, C.; Fonseca, H.; Calori-Domingues, M.A.; Glória, E.M.; Borguini, R.G.; Silveira, V.P.; Piedade, S.S.; Barbin, D. Seleção eletrônica pela cor na descontaminação de amendoim contaminado com aflatoxinas. Sci. Agríc., 56: 371-376, 1999. 